1. Breslin, P. A. S., Gingerich, T. N. \& Green, B. G. Chem. Sens. 26, 55-66 (2001).

2. Andrewes, P., Busch, J. L. H. C., De Joode, T.

Groenewegen, A.\& Alexandre, H. J. Agric. Food Chem. 51, 1415-1420 (2003).

3. Fischer, R., Griffen, F., Archer, R. C., Zinsmeister, S. C. \& Jastram, P. S. Nature 207, 1049-1053 (1965).

4. Vane, J. R. \& Botting, R. M. Inflamm. Res. 44, 1-10 (1995)

5. Harris, R. E., Beebe-Donk, J., Doss, H. \& Burr Doss, D. Oncol. Rep. 13, 559-583 (2005).

6. Zhou, Y. et al. Science 302, 1215-1217 (2003)

7. Hu, F. N. Engl. J. Med. 348, 2595-2596 (2003)

8. Tuck, K., Freeman, M., Hayball, P., Stretch, G. \& Stupans, I. J. Nutr. 131, 1993-1996 (2001)
9. Miro-Casas, E. et al. Clin. Chem. 49, 945-952 (2003).

10. Hennekens, C. H. Am. J. Man. Care 8 (suppl.), 691-700 (2002).

11. Lefer, A. M., Muller, H. F. \& Smith, J. B. Br. J.Pharmacol. 83, 125-130 (1984)

12. Togna, G. I., Togna, A. R., Franconi, M., Marra, C. \& Guiso, M. J. Nutr. 133, 2532-2536 (2003).

13. Mitchell, J. A. et al. Proc. Natl Acad. Sci. USA 90, 11693-11697 (1993).

Supplementary information accompanies this communication on Nature's website. Competing financial interests: declared none. doi:10.1038/437045a

\title{
GEOPHYSICS
}

\section{A moving fluid pulse in a fault zone}

In the Gulf of Mexico, fault zones are linked with a complex and dynamic system of plumbing in the Earth's subsurface. Here we use time-lapse seismic-reflection imaging to reveal a pulse of fluid ascending rapidly inside one of these fault zones. Such intermittent fault 'burping' is likely to be an important factor in the migration of subsurface hydrocarbons.

Faults have a dual function in that they can act as both an impediment to and, at times, a preferential pathway for fluid flow. Both types of behaviour are invoked in the petroleum industry to explain how hydrocarbons move from the location at which they are generated (for example, by flowing along faults ${ }^{1}$ ) into fault-bounded reservoirs where they become trapped (for example, by a lack of flow across faults ${ }^{2}$ ). Several lines of evidence from the South Eugene Island Block 330 field, offshore Louisiana, USA, indicate that faults cutting through sequences of Pliocene and Quaternary sands and shales have hosted significant vertical fluid flow over the past 250,000 years, continuing to the present day ${ }^{3-5}$.

We present an additional set of data obtained from seismic reflection imaging that indicates fast fluid movement (more than 100 metres per year) along growth faults. Previously, we have demonstrated that reflections from the fault planes appearing in seismic data from South Eugene Island Block 330 contain information about the distribution of fluid pressures across faults ${ }^{6}$.

The South Eugene Island field is an ideal location for this study. Multiple vintages of seismic-reflection surveys can be interpreted in the context of abundant fluid pressure, geochemical and other data. Normal faults transect the field at dips of about $50^{\circ}$ southwest and separate upthrown sediments saturated by highly pressurized fluids from relatively less pressurized downthrown sediments (see supplementary information). The fault zones are typically at the same pressure as the upthrown sediments ${ }^{4}$. However, exceptionally pressurized fluid was encountered in one penetration of a growth fault, the B-fault, in the A10ST well $^{3,4}$. It was proposed that the isolated pocket of anomalously high fluid pressure in the A10ST well could represent a spatially limited pulse of anomalously pressured fluid ${ }^{4}$.

To test the idea of a moving fluid pulse, or fault burp, we isolated the fault-plane reflec-
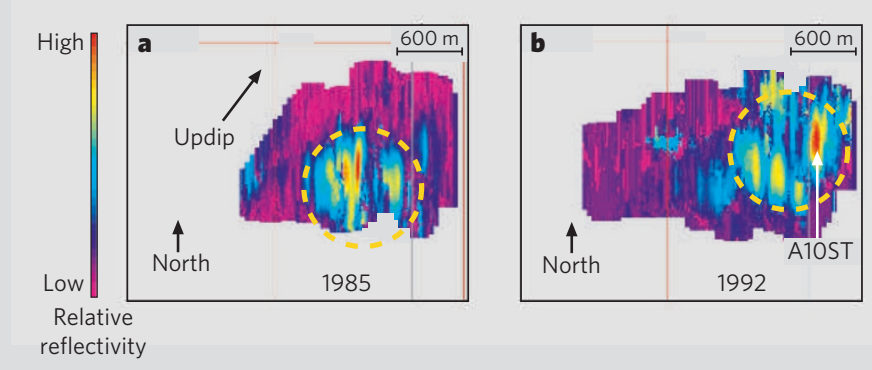

Figure 1 A fault caught in the act of burping. a, Map of the B-fault showing reflectivity from the fault plane in 1985 . The area of highest reflectivity is circled in gold. b, Map of the B-fault reflectivity, as shown in a, but from 1992. The data extend over a slightly larger area than in a; however, the spatial perspective is identical. The area of highest reflectivity, circled in gold, is shifted roughly $1 \mathrm{~km}$ north-east in the updip direction relative to its location in 1985, as would be expected for a fluid pulse ascending the Bfault; this movement is depicted by the arrow in a. Also shown is the location of the A10ST well intersection, where exceptionally high fluid pressures were encountered while drilling into the B-fault zone in 1993. tions from the B-fault in images derived from seismic surveys taken in 1985 and 1992 and looked for indications of movement. In Fig. 1, we show reflectivity as a function of position on the fault plane for both sets of data. Patches of high reflectivity, or 'bright spots', are known to be associated with the presence of fluids ${ }^{7}$. The most striking pattern in the fault reflectivity maps is the northeast movement of the areas of highest reflectivity between 1985 and 1992. This movement, in the updip direction, is to be expected for a fluid pulse ascending the B-fault. Also note the correlation between the area of highest reflectivity in 1992 and the location of the intersection with the A10ST well (Fig. 1b), where highly pressurized fluid in the fault was observed in 1993 (ref. 4).

From the reflectivity maps at the B-fault, we estimate the movement of the fluid pulse to be of the order of $1 \mathrm{~km}$ between 1985 and 1992. The observed movement of $1 \mathrm{~km}$ is significant compared with typical errors encountered in the processing of seismic data (see supplementary information). Movement of $1 \mathrm{~km}$ between 1985 and 1992 corresponds to an average pulse speed of about $140 \mathrm{~m} \mathrm{yr}^{-1}$. Such geologically fast fluid flow up a vertically permeable fault agrees with the dynamic-capacity model of fault-bounded reservoirs ${ }^{8}$ and is consistent with a nonlinear fluid-flow model involving pressure-dependent permeability 9 . These fault burps are key to the understanding of fluid-migration mechanisms and fault-zone rheology in the Earth's crust.

Matthew M. Haney ${ }^{\star} \uparrow$, Roel Snieder ${ }^{\star}$,

Jon Sheiman

${ }^{\star}$ Center for Wave Phenomena and Department of Geophysics, Colorado School of Mines, Golden,

Colorado 80401, USA

e-mail:mmhaney@sandia.gov

†Shell International Exploration \& Production,

Houston, Texas 77025, USA

§Department of Earth and Atmospheric Sciences, Cornell University, Ithaca, New York 14853, USA

$\uparrow$ Present addresses: Sandia National

Laboratories, Geophysics Department, PO Box 5800 MS 0750, Albuquerque, New Mexico 87185-0750, USA (M.H.); Department of Chemistry and Geology, Minnesota State University, TN242, Mankato, Minnesota 56001, USA (S.L.).

1. Hooper, E. C. D. J. Petrol. Geol. 14, 161-180 (1991).

2. Holland, D. S., Leedy, J. B. \& Lammlein, D. R. in Structural Traps III, Tectonic Fold and Fault Traps: AAPG Treatise of Petroleum Geology Atlas of Oil and Gas Fields (eds Beaumont, E. A. \& Foster, N. H.) 103-143 (AAPG, Tulsa, 1990).

3. Anderson, R. N., He, W., Hobart, M. A., Wilkinson, C. R. \& Roice, H. R. The Leading Edge 10, 12-17 (1991)

4. Losh, S., Eglinton, L., Schoell, M. \& Wood, J. AAPG Bull. 83, 244-276 (1999).

5. Whelan, J. K., Eglinton, L., Kennicutt, M. C. II \& Qian, Y Geochim. Cosmochim. Acta 65, 3529-3555 (2001).

6. Haney, M. et al. in Proc. EAGE Spec. Sess. Fault and Top Seals (eds Engelder, T., Konstanty, J. \& Grauls, D.) 0-7 (EAGE, Houten, 2004).

7. Dobrin, M. B. Introduction to Geophysical Prospecting (McGraw-Hill, New York, 1976).

8. Finkbeiner, T., Zoback, M. D., Stump, B. \& Flemings, P. AAPG Bull. 85, 1007-1031 (2001).

9. Rice, J. R. in Fault Mechanics and Transport Properties of Rocks (eds Evans, B. \& Wong, T.-F.) 475-503 (Academic, San Diego, 1992).

Supplementary information accompanies this communication on Nature's web site. Competing financial interests: declared none. doi: $10.1038 / 437046 a$

BRIEF COMMUNICATIONS ARISING online www.nature.com/bca see Nature contents. 